\title{
Controversy and Critical Exhibitions: Envisioning a Fourth Generation of Science Museums
}

\author{
Léonie J. Rennie ${ }^{1}$
}

Accepted: 9 March 2021/Published online: 23 March 2021

(C) Ontario Institute for Studies in Education (OISE) 2021

\begin{abstract}
The book Controversy in Science Museums: Re-imagining Exhibition Spaces and Practice by Erminia Pedretti and Ana Maria Navas Iannini presents a masterful analysis of the nature of science museums and their exhibitions. Critical exhibitions challenge how science is represented traditionally and can be transformative by inspiring visitors to grapple intelligently with the serious socio-scientific issues encountered in their everyday lives. The book is an elegant exposition of theory, practice, and research, compiled by authors who know and understand this genre of science museum exhibitions. This review explores the themes that enable the authors to provide a thought-provoking, practical analysis that can assist the leaders of science museums to further the successful evolution of transformative and critical exhibitions.
\end{abstract}

Résumé L'ouvrage d'Erminia Pedretti et Ana Maria Navas Iannini intitulé «Controversy in Science Museums: Re-imagining Exhibition Spaces and Practice (Controverse dans les musées des sciences: repenser les lieux et les méthodes d'exposition)» offre aux lecteurs une magistrale analyse de ce que sont les musées à vocation scientifique et leurs expositions. Les expositions critiques remettent en question les représentations traditionnelles faites de la science et peuvent s'avérer transformatrices par leur capacité à inspirer les visiteurs à composer de façon intelligente avec les importants enjeux socioscientifiques qui se présentent dans leur quotidien. L'ouvrage s'avère une élégante compilation de théorie, de pratique et de recherche, rédigée par des auteurs qui connaissent et comprennent ce genre d'expositions muséales scientifiques. Ce compte rendu se penche sur les thèmes permettant aux auteurs de proposer une analyse pratique qui donne à réfléchir et qui peut aider les gestionnaires de musées des sciences à poursuivre plus avant l'évolution fructueuse d'expositions critiques et transformatrices.

Keywords Science museums $\cdot$ Controversy $\cdot$ Exhibitions

Controversy in Science Museums: Re-imagining Exhibition Spaces and Practice is a very significant contribution to museology, particularly for those science museum professionals who realise that their institutions have a responsibility to their community to provide access to the science relating to contemporary,

Léonie J. Rennie

1.rennie@ curtin.edu.au

1 School of Education, Curtin University, GPO Box U1987, Perth Western 6845, Australia 
contested and controversial issues. The book is beautifully written by Erminia Pedretti and Ana Maria Navas Iannini, researchers who have abundant experience in working with science museum exhibitions that communicate controversy. Nearly two decades ago, Pedretti established herself as a leading thinker in this aspect of science communication by capturing the elusive essence of controversial exhibitions and how they shape visitors' experiences (Pedretti, 2002). In her paper entitled T. Kuhn Meets T. Rex: Critical Conversations and New Directions in Science Centres and Science Museums, Pedretti referred to critical exhibitions that were issues-based, rather than object- or concept-based, and made explicit that science is neither objective nor value-free but is contextualised by a complexity of social, cultural, and political values. More recently, she has continued this work with Navas Iannini and together they have broadened the investigation of controversial exhibitions both geographically and socio-culturally. Not surprisingly, I looked forward to reading this book and I was not disappointed.

Pedretti and Navas Iannini (2020) articulated their overall goal for the book: "In a nutshell, [it] is to explore changing directions in the science museum landscape, with a focus on controversy in theory and practice" (p. 2), and they have achieved this goal, compellingly. The book itself is sensibly laid out in three sections, each with four chapters, providing a nice balance of theory, research-based case studies of controversial exhibitions, and a "putting-it-altogether" section, that draws together theoretical and research threads and envisions feasible futures. In this review, I will précis each chapter, in part to demonstrate just how much terrain this book covers, but primarily, I attempt to pull out the themes that highlight the authors' intentions to provide a thought-provoking yet practical analysis that can assist the professional staff of science museums to further the successful evolution of controversial exhibitions. Such exhibitions challenge the traditional representations of science and inspire visitors to grapple intelligently with the serious socio-scientific issues that challenge them in their everyday lives.

The four chapters in Part 1 have a similar structure; an overview of the theoretical and/or historical background to the constructs considered, leading to their adaptation or extension into the realms of science museums (this term includes science centres and similar institutions). Chapter 1 is devoted to scientific literacy. Following a synthesis of its origins, this oft-times slippery concept is pegged down by contextualising it with aspects of citizenship and the values-social, political, cultural, economic, environmental-inherent in decision-making. The authors refer to Hodson's (2003) four dimensions of science and technology education as a basis for moving from engagement in science and technology, to the more critical dimension of "engaging in socio-political action", enabling citizens to acquire the skills to work actively towards social, political and environmental transformation, that is, to participate in informed decision-making in just and respectful ways.

This perspective is linked to themes about "science-in-context"-socio-scientific issues (SSI), socially acute questions (SAQ), and science, technology, society and environment (STSE) - and the possibility of science museums promoting progressive views of a critical scientific literacy, empowering citizens to participate constructively in the socio-cultural issues that confront them. SSI, SAQ and STSE are conventional acronyms for conceptions of science-in-context that are dealt with skilfully and adequately here, but readers may wish to visit Bencze et al. (2020) for an extended description.

An exploration of the relationship between science communication and public engagement in science is tackled in Chap. 2 by analysing how these constructs have become established in our thinking in the sphere of science museums over the last several decades. The familiar deficit-dialogic-participation models of science communication, with their inherent hierarchy of passive to active public participation, is extended by the authors to include a fourth model—dissent and conflict/action — with the goal of agency and action on the part of the public. This goal, argue the authors, is more in keeping with science museums working towards delivering exhibitions with the potential to effectively engage the public in communication about controversial science-related issues.

The evolution of science museums is discussed in Chap. 3, building cleverly on the "generational" notion suggested three decades ago by McManus (1992). Science museums began with "cabinets of 
curiosities"; displays of interesting objects collected during voyages of discovery. These "first generation" exhibitions simply displayed objects for wonderment and were followed by a second generation where science and technology were presented in applied ways (think steam engines!) that were intended to make the relevant scientific and technological ideas more accessible to the public. Third generation science museums focus on science concepts in action and are exemplified by science centres where objects are built specifically to encourage learning of the (often decontextualised) concepts through interaction and play.

The authors propose a fourth generation of science museums, those with a focus on visitor participation through talk, interaction and the potential for decision-making about significant science-related issues. This big jump of focus-from objects to audience-requires a big change in the nature of the exhibits; the range of pedagogical and experiential types of the third generation must be extended and complemented by exhibits described by the authors as critical and agential. When exhibitions deal with topics that are challenging and controversial, they are emotionally charged and can be agential in that visitors are encouraged to act in relation to the content. Pedretti and Navas Iannini (2020) present a useful typology of science museum exhibitions (see Table 3.1, p. 61) and synthesise the premise of the chapter with a list of the characteristics of the fourth generation science museums, repeated here because of their salience in the subsequent discussion.

The emergent fourth generation science museum (1) challenges dominant cultural and scientific narratives; (2) brings together various disciplines; (3) recognises the complex and often messy relationships that co-exist: (4) asks critical questions; (5) invites civic participation, reflexivity, and engagement; and (6) works toward agency, and ultimately, social change. (p. 63)

Chapter 4 is one of the most important in this book because it tackles the construct of controversy. A clear understanding of controversy in the context of science museums is essential to make meaning of the book's arguments. It is, as the authors point out, "a term that is bandied about by many, but deconstructed by few" (p. 66). The chapter itself is written masterfully in keeping to its task: what is controversy and how can science museums engage with it? From a broad-based background, the authors move quickly to controversy in science museum exhibitions. It becomes clear that exhibitions can be about controversy (e.g. those that deal with unfinished science, those portraying conflicting perspectives) or, more provocatively, can generate controversy (e.g. those that engage different beliefs and values, contentious applications of scientific knowledge). Communicating controversy, engaging visitors and challenging conventions are dealt with deftly: controversial exhibitions "disrupt and challenge politically safe images and representations of science and seek a level of visitor engagement that moves beyond passively receiving knowledge" (p. 81).

Part 1 concludes (as does each of the other sections) with some reflective questions and two or three thought-provoking activities designed to assist consolidation of the ideas introduced. These additions not only make the volume suitable for graduate classes, but the activities could be "workshopped" by staff in science museums to promote discussion and inspire ideas to be applied in their own institution.

The middle section of the book comprises four chapters that each portrays a particular controversial exhibition through data collected by the authors, and all are generously illustrated with well-chosen photographs. Chapter 5 describes the iconic 20-year-old exhibition, A Question of Truth, at the Ontario Science Centre in Canada; iconic because, whilst undeniably bold at its inception, being critical and issues-based, it has become a symbol for questioning the science of the day. Described through interviews with various staff, it becomes evident that this is an exhibition that is not only about controversy, but it also generates controversy. Its longevity speaks for its impact and efficacy. This is the only one of the four exhibitions described in this section that I have visited myself. I knew of it through Pedretti's earlier work as an exhibition that personalised its subject in ways that evoked emotion and promoted reflexivity by stimulating dialogue and debate (Pedretti, 2002, 2004). Even though mine was an "informed" visit, I found the exhibition deeply moving. 
Preventing Youth Pregnancy, the focus of Chap. 6, was installed for a period of 6 years at the Catavento Museum in São Paulo, Brazil, to speak to teenagers about matters of sexuality and sexual practices. It was developed in association with the Kaplan Institute, which had prepared school curriculum materials relating to sexuality and sex education. The enthralling account of its origins, life, effects and closure through lack of funding (the full-time attendance of sex educators and psychologists was a major expense) is told by the voices of staff from the museum and Kaplan Institute. It is the story of an exhibition that clearly generated controversy; it was underpinned by tensions and struggles for the organisers but created valuable opportunities to empower the autonomy and decision-making skills of the attendant youth. It was also an exhibition that illustrated how each of the four models of science communication-deficit, dialogue, participation, and dissent and conflict/action—can be balanced to promote communication of the intended messages.

Chapter 7 details two of Gunther von Hagens' exhibitions of plastinated cadavers, Body Worlds and the Story of the Heart at the Ontario Science Centre and Body Worlds: Animal Inside Out at the Canadian Museum of Nature, Ottawa. Perhaps more than the other exhibitions described in the book, the "real" nature of the Body Worlds exhibits engenders powerful emotions in some people, to the extent that signs warning of their reality are displayed outside of the exhibition. Using interviews from staff, Pedretti and Navas Iannini carefully recount the turbulent background to the exhibitions, the decisions to mount them and their potential to teach, to enlighten and, in this age of fiscal constraint, to generate revenue. Central to the controversial nature of the Body Worlds exhibitions is the "medium" itself; the exhibits are "objects" that once were living beings, and this opens ethical questions about how different societies deal with their dead. As the authors suggest, it can boil down to a balance between the educative goal of teaching about anatomy and respectful sensationalism.

The fourth exhibition, described in Chap. 8, was developed at Heureka the Finnish Science Centre and borrowed then translated and modified by the Science Museum of Minnesota in Minneapolis. Mental Health: Mind Matters (originally called Heureka Goes Crazy) aims to raise awareness of illnesses such as anxiety, depression and various psychoses, mental disorders that are common in society but frequently not brought into the open. Exhibits include dioramas and places where visitors can hear audio voices, see photographs and read the autobiographical accounts of sufferers of mental illnesses. There is also a space offering resources and information about mental health. Drawing on information from documents and staff at Heureka and the Science Museum of Minnesota, the authors weave a rich a tapestry of the groundwork done by the Finnish originators of the exhibition and the mindful modifications made for exhibition in the USA. This background preserved the original goals of raising awareness of mental health, engaging visitors in ways that develop empathy, with a balance between scientific knowledge and expertise and people's personal testimonials. This is an exhibition in which the issues on display can become discomforting when visitors recognize the immediacy of mental health personally or in others close to them, and thus generate controversy in critical and agential ways. It is an exhibition that can strike home with a thud.

Thus far, little has been said about visitors' actual experiences at these critical and controversial exhibitions. Chapter 9 opens Sect. 3 by addressing this absence. Pedretti and Navas Iannini employ a cross-case analysis to analyse the nature of visitors' engagement with the four exhibitions described in Sect. 2. In addition to the interviews with museum professionals accessed in Part 2, data from the case studies include visitor interviews, observations and field notes, and comment cards. These data speak eloquently about visitors' emotional connections with the exhibits and how they felt challenged, emotionally and intellectually, by the content. Interestingly, many visitors wanted more information on some points; there seemed to be no "swamping" of information. The importance of stories came to the fore; opportunities to talk and listen in the exhibitions enabled visitors to initiate stories of their own, complementing those told through the exhibits. This suggests a sense of agency, with visitors making connections between themselves and the exhibition themes. The authors present a somewhat muted 
conclusion because it is not possible to know if visitors actually enacted their intentions after their visit. Nevertheless, the findings draw attention to the hope and promising possibilities for learning about science, engaging in action, and two-way communication through these controversial themes.

Chapter 10 returns to the voices of the science museum professionals to answer questions about why they wanted to mount these controversial exhibitions. What were their goals? Delving into the data available, Pedretti and Navas Iannini structure the answers around several themes that underpin the nature of critical and controversial exhibitions and the debates about scientific literacy, communication and public engagement discussed in Part 1. The museum professionals expressed the desire to be provocative and challenge visitors' beliefs about science; they re-thought how visitors could be engaged and how the emotional aspects of exhibit themes could be made tangible. Models of science communication are re-visited; how could the dialogical and participation models be engaged more actively, and how could the notion of controversy be employed to encourage visitors to think and, hopefully, act in transformative ways. In this chapter, we see how the characteristics of fourth generation of science museums (see earlier) are emerging. Not surprisingly, moving towards this fourth generation incurs costs, costs not only in funding but costs to the science museum itself.

Chapter 11 is dedicated to the ways in which these science museums were able to "navigate" the doubts and disagreements inherent in being controversial. The museum's own identity, the expectations of its community, the conditions set by potential sponsors and dissonance amongst staff are all considered. Once these issues are sorted out, there remain the needs to structure the physical environment, consider the language to be used and train staff to support visitors through their responses to controversy. This chapter deserves several readings because the learning experiences of the museum professionals who have "been there" offer much to inform other staff embarking on the journey to mount a controversial exhibition.

The final chapter is short but sure. Entitled "Science Museums Re-imagined", Chap. 12 brings it all together. Under the umbrella of the envisioned fourth generation science museum, the theoretical underpinnings from Part 1 are revisited, informed by the data and their analysis in Chaps. 5 through 11. Critical scientific literacy, the models of communication and the nature of controversy itself are synthesised, and six drivers are defined that can underpin the fourth generation science museums as "hubs of change/transformation" (p. 232). Pedretti and Navas Iannini "firmly believe that science museums and their exhibitions can become places for change and transformation, productive struggle, allyship, empathy, epistemic democracy, and can serve as a third hybrid space" (p. 238). They point out that science museums must not exist for their own sakes, but "embrace their active mutuality within the societies in which they exist" (p. 238). I think these authors are right, and this book is a mighty step towards showing science museum professionals how this might be done.

This book is an elegant exposition of theory, practice and research, compiled by authors who know and understand this genre of science museum exhibitions. It deserves a place on the shelf of every serious museum professional and researcher.

Endnote: The book was written in the context of a rapidly changing international landscape, but just before it went to press, the world was suddenly in lockdown for the first wave of the COVID-19 pandemic. In a codicil at the end of the introduction, the authors refer to the current closure of science museums and wonder how, when they re-open, "they will be re-imagined to inform, educate and empower citizens to be part of healthy democratic societies" (p. 9). As I write this review, many countries are again in lockdown with their second or third wave of the pandemic, and we have yet to see how science museums respond. My hope is that their respective leaders have profited by spending some of their lockdown time in reading this book. 


\section{Declarations}

Conflict of Interest The author declares that there is no conflict of interest.

\section{References}

Bencze, L., Pouliot, C., Pedretti, E., Simonneaux, L., Simonneaux, J., \& Zeidler, D. (2020). SAQ, SSI and STSE education: defending and extending "science-in-context". Cultural Studies of Science Education, 15, 825-851 https://doi. org/10.1007/s11422-019-09962-7.

Hodson, D. (2003). Time for action: Science education for an alternative future. International Journal of Science Education, 25(6), 645-670 https://doi.org/10.1080/09500690305021.

McManus, P. M. (1992). Topics in museums and science education. Studies in Science Education, 20, 157-182 https:// doi.org/10.1080/03057269208560007.

Pedretti, E. (2002). T. Kuhn meets T. Rex: Critical conversations and new directions in science centres and science museums. Studies in Science Education, 37, 1-42 https://doi.org/10.1080/03057260208560176.

Pedretti, E. (2004). Perspectives on learning through critical issued-based science center exhibits. Science Education, 88(Suppl. 1), S34-S47 https://doi.org/10.1002/sce.20019.

Pedretti, E. \& Navas Iannini, A. M. (2020). Controversy in science museums: Re-imagining exhibition spaces and practice. Routledge: London.

Publisher's Note Springer Nature remains neutral with regard to jurisdictional claims in published maps and institutional affiliations. 